\title{
Review
}

\section{The Meanings of Human Rights}

\author{
Human Rights, Human Dignity, and Cosmopolitan Ideals \\ Matthias Lutz-Bachmann and Amos Nascimento, \\ Ashgate, Farnham, 2014, 188pp., ISBN: 978-1409442950
}

\author{
The Meanings of Rights: The Philosophy and Social Theory of Human Rights \\ Costas Douzinas and Conor Gearty, \\ Cambridge University Press, Cambridge, 2014, 368pp., ISBN: 978-1107679597
}

Contemporary Political Theory (2016) 15, e15-e24. doi:10.1057/cpt.2015.12;

published online 17 March 2015

Human rights have become ubiquitous; it is feared that consequently they have become meaningless - claimed by any and every political actor seeking the moral high ground. The authors in these volumes, in their varied ways, show that the radical and critical potential of human rights is not exhausted by their contemporary institutionalization, or their instrumentalized appropriation. They demonstrate both the emancipatory potential of human rights and the commitment of scholars to hold to account those who would claim to work under their remit.

Lutz-Bachmann and Nascimento's volume is the textual manifestation of an ongoing scholarly dialog 'on the meaning and importance of human rights and their relationship with conceptions of human dignity and cosmopolitanism' (p. 1). Each of the contributors to the volume is tasked to pursue three goals with their efforts: 'To reconstruct modern philosophical theories that have contributed to our views on human rights and issues of global justice; to highlight the importance of humanity and human dignity as a complementary dimension to liberal rights; and, finally, to integrate these issues more directly in contemporary discussions about cosmopolitanism' (p. 1). More broadly, the volume as a whole sets itself the goal of contributing to and helping to establish and delineate an emerging field, which they nominate the 'Critical Theory of Human Rights'. This field is, on the one hand, very broad: it crosses a range of disciplines, those particularly listed being philosophy, law, political theory, sociology, and international relations. On the other hand, there is a certain narrowness to the understanding of what this critical theory of human rights might consist in: the field - at least as delineated by the scholars in this book - is to be found between those positions that are marked out by John Rawls and Jürgen Habermas. Although there is much to be said within that space, this marking does suggest the reorganization of rather conventional critical theoretical debates along

(C) 2016 Macmillan Publishers Ltd. 1470-8914 Contemporary Political Theory Vol. 15, 1, e15-e24 
human rights themes, rather than the delineation of an emerging field. I will briefly discuss each of the seven chapters.

Matthias Lutz-Bachmann's designated introductory chapter touches on many of the common themes in the book, but otherwise follows its own agenda: to critique existing accounts of the relationship between ethics and politics in the political philosophy of international relations; to propose an alternative in the light of 'new realities in world politics'; and to specify how this applies to human rights. LutzBachmann effectively highlights the limitations of thinking global ethics and politics through the now well-worn frameworks of realism, liberalism and communitarianism. His agenda of offering a new perspective might have been more effective if it had engaged with some of the work within International Relations that has long recognized that the realist/liberal/communitarian discussions of state sovereignty do not adequately engage the 'new realities' of global politics to which Lutz-Bachmann refers. The bulk of the essay is spent presenting a reconstruction of human rights theory based on a pre-political fundamental right to the justification of norms. Although this is persuasive on its own terms, the author only gestures briefly as to how this theory of human rights engages with 'the realities of world politics' in his title. The gesture is enough to introduce us to one of the main recurrent themes of this volume, however, which is precisely whether our theoretical understandings of human rights should be derived from moral or other first principles or from the vexed realities of human rights in the world.

William J. Talbott provides the principal Rawlsian contribution to the volume in a piece that speculates about the efficacy of an 'expanded original position (EOP) test' in predicting moral transformations of humanity. The EOP test is designed to model the ways in which 'empathy and concern for fairness as judged from an impartial point of view' can help us understand what human dignity requires (p. 25). Having set out the EOP test, and looked at how its progenitors, such as Kant's predictions in Perpetual Peace, were extremely effective, Talbott argues that it should be used to predict future moral transformations. Although Rawls's original position was an intellectual device for abstract use, Talbott is keen to run his test on actual populations of people. Talbott hopes that the EOP will survive empirical tests, and become an authority in political debates (such as assisted suicide, a policy Talbott thinks the EOP would support), but he does not discuss the political consequences of such an outcome.

The next two chapters directly engage the question: How should we theorize human rights? The first chapter, 'Global Governance and Human Right' by Cristina Lafont, advances a practical (or practice) approach to theorizing human rights. Then 'Are human rights moral rights?' by Andreas Neiderberger? provides an account in which the difference between what Lafont calls the practical and traditional approaches is articulated in detail, and in which he supports the former. It seems to me that the more general argument of this chapter would have been better placed before the more specific one from Lafont. 
Neiderberger commences by recognizing that many philosophers do not wish to start theorizing from the existing human rights regime because of its 'major deficiencies' (p. 75). The point of a moral theory of human rights is to provide moral foundations for human rights, to provide for their universalism and their application to all of humanity, and - crucially - to provide guidance against these deficiencies. Neiderberger argues that moral rights theories of human rights end up being too revisionist to be particularly helpful. The human rights that occur in the real world do not generally qualify theoretically; moral philosophers like to 're-invent' human rights, and by going down this path they deal themselves out of useful engagement on the ground. Neiderberger then sets out the reconstructive alternative, which while avoiding the above issues, encounters others, including 'an underdetermined definition' that risks letting any kind of harm caused by power differentials become a human rights issue. Neiderberger argues that working within these debates within actually existing law and politics is how philosophers can best strengthen human rights.

If we then turn to Lafont, we find ourselves with an excellent example of how philosophy can help us with the human rights regime as we find it. Lafont situates herself as a proponent of the practice - or as she prefers to call it, the practical approach to human rights: 'it is by understanding the point of the practice of human rights that we understand what human rights actually are' (p. 49). Correctly identifying that point becomes crucial. (In)famously, for Rawls the point of human rights is to act as an intervention trigger against states. Lafont argues that this is not the point or function of human rights within the practice of human rights; moreover, she critiques Rawls and Beitz and others for their state-centric versions of a practice account. Human rights 'would still have a point in the absence of a division of political space by states [therefore] it cannot be the case that the distinctive function of human rights is to regulate the behaviour of states by setting limits on their sovereignty' (p. 53). The bulk of her essay - the longest, and in my opinion the most original and important in the volume - is taken up with presenting and defending her alternative practical account of human rights. This alternative account accepts that human rights are triggers for international action, but argues that 'nothing about the norms constitutive of this practice justifies the restrictions of possible "violators" to states and of the appropriate "actions" to interventions against a state's sovereignty' (p. 60). From here Lafont goes on to argue the 'dynamic character of human rights norms', to develop a 'pluralist conception of human rights obligations' and a 'structural approach to human rights protections' (pp. 61, 67, 69). Lafont sets a powerful agenda for how to think about human rights in a rapidly changing institutional environment.

Part 2 of the volume commences with two essays that directly engage the recent literature on cosmopolitanism. In keeping with one of the express goals of the volume, Amos Nascimento seeks to use a survey of the paradigms of cosmopolitanism to move 'from rights to humanity'. The early part of his essay chimes sympathetically with Lafont in its argument against state-based accounts of human 
rights. Such views are stuck in the nineteenth century and do not recognize the many agents sub- and supra- to the state. He also rejects any kind of legalist restriction on human rights. Nascimento's principal concern appears to be that formal rightsoriented discourse has lost an emphasis on the human, leading to a loss of voice for the subaltern, forgotten and oppressed, in turn leading to a loss of both their rights and their humanity. What is not addressed here is how this human dimension should then be put into our models of rights and other cosmopolitan political institutions and practices - so that it has some significance for those presently being dehumanized.

Eduardo Mendieta commences his stimulating discussion by acknowledging that many past cosmopolitanisms have not been particularly interested in this universal notion of the human or of humanity. Cosmopolitanisms, rather, have been born out of selective privilege - economic, political, cultural, linguistic. Mendieta's purpose is 'to foreground the ways in which the materiality that enables cosmopolitanism must itself be a part of the self-reflection on how to be and not to be cosmopolitan' (p. 121). To do this he takes cosmopolitanism's poster boy Kant, and subjects him to close scrutiny, based on much recent scholarship (not all yet available in English) on Kant's Physical Geography lecture course, and its relationship to his other writings. Kant was an imperial cosmopolitan: he 'consciously and uncritically assumed the privileges of his citizenship and location within the Austrian Empire ...' (p. 124). Mendieta comments further, "once we have undone the "traces" of racist and Eurocentric anthropological and geographical assumptions and preconceptions in Kant's cosmopolitanism, little may remain' (p. 129). Imperial cosmopolitanism is to be rejected in favor of a dialogical account. Nussbaum, Appiah, Mignolo, Butler, and Benhabib all feed into this account - an account that, if sufficiently attuned to its materiality in certain institutions and histories ... may become an emancipatory form ...' (p. 134). There is much here about empathies, solidarities, and dialogical imaginations, but less that comes back to the crucial question of the materiality of such an emancipatory politics and its preconditions. It is perhaps more urgent to ask this question of ourselves in our neoliberal times than it is to ask it of Kant, however enlightening that important discussion might be.

James Tully does precisely this in the essay that closes the volume. He identifies two traditions of human rights. One lines up with Mendieta's imperial cosmopolitanism; the other, as Tully puts it, sees human rights as proposals among humans. These proposals, rather than being declared by an authority as self-evident, 'gain their normative force by being reflexively tested, interpreted and negotiated en passant' (p. 140). They are democratic and non-violent. The former High Enlightenment tradition traces human rights as European-originating ideas and institutions associated with empire, modernization, and colonialization. The key to this tradition is its Hobbesian premise 'that the state institutions of modern rights are prior to, and the condition of civilized relationships of cooperation and socialization' (p. 141). This legitimates any amount of violence in the forming and shaping of populations into subjects of modern global governance in the name of human rights. Tully's alternative tradition is traced through movements 
of non-violent grass roots protest and democratic activism. Philosophically, the marker human stands for cooperation, not competition, and neither human labor nor the environment should be understood as a commodity in market relations. Tully fittingly brings together many of the book's most powerful themes in his closing pean to an ethos of 'democratic human rights enlightenment'.

The first section of the volume edited by Douzinas and Gearty concerns the foundations of human rights - foundations that, notwithstanding the large amount of literature devoted to their discussion, remain elusive. Four authors tackle this subject: Jean-Luc Nancy, Conor Gearty, John Milbank and Rowan Williams. Much of the tone of this volume is set by Nancy's piece 'two simple remarks' on human rights which are in fact multiple, anything but simple and settle nothing. Nancy insists in his first 'remark' that the 1948 Universal Declaration of Human Rights forces us to enter a philosophical register, although he fears that mostly the philosophical roots of the Declaration are 'written off' and that today 'human rights float more or less on the surface of the "icy water of egotistical calculation"' (p. 17, quoting Marx and Engels). In his second remark he forces us to face the difficulty of 'founding right', which is brought to light by our attempts to justify human rights - indeed, he avers that the 'greatest merit' of human rights is its capacity to confront us with these difficulties and exigencies (p. 20).

Conor Gearty relishes the confrontation, executes a sudden turn and plunges the reader into the volume's only sustained engagement with the naturalistic sciences and their impact upon ethics. Gearty is inspired by Philip Kitcher, who in The Ethical Project seeks 'to bring together post-Darwinian fatalism about the self with human reason's not unreasonable desire to keep itself at the centre of our species-story' (p. 21). Gearty argues that human rights should be understood as a 'visibility project', the goal of which is to see people as people and therefore treat them correctly - to include them within the expanding circle of care. This, he says, is the popular understanding of human rights. Moreover, because of its affinity with altruism, and because of the role of altruism and cooperation in evolutionary ethics, human rights may be understood as a 'commitment gadget' that provides us with normative guidance against violence and toward mutual recognition in the world at large (p. 23).

Gearty notes in passing that those holding orthodox readings of human rights would 'hate all this stuff' (p. 24) - and one presumes this is true of the next two contributors, Christian theologians Milbank and Williams. While erudite and of interest, their theological vision feels out of sync with the rest of this broadly 'leftcritical' collection, particularly Milbank's call to revive doctrines of objective ius from the Dominican Middle Ages as the only true way to equitable egalitarianism. For the book to have two such Christian contributions and none (critical or otherwise) from other religious traditions seems distinctly unfortunate.

Milbank's piece is nonetheless a key contribution to the deep ideational history of right, liberty, freedom and absolutism. He is, as his title declares, against human rights. Human rights is not the 'high mead, the finest distillation of the western 
tradition'; rather, their promotion will hasten the collapse of the western legacy. Williams, in turn, does not seek to reset the contemporary human rights discourse with a neoorthodox Christian theology, although he does start with MacIntyre's famous claim that human rights do not exist - being fictions like witches and unicorns. Williams' goal is to salvage what MacIntyre thought had become a language of mere assertion by showing that a particular Christian theological tradition can be used to ground the discourse. Although he mentions in passing that this may be done by other religious traditions too, he dismisses the possibility of a secular account: such a thing is 'always going to be problematic' (p. 80). Unlike theology!

The focus of the first two essays in the second section, 'Law, rights and revolution', is on the disruptive potential of rights. Costas Douzinas asks whether there is a right to revolution; Illan Rua Wall takes up a term earlier posited by Douzinas, 'right-ing', and uses it to consider new rights - and the reuse of old ones. The key idea behind right-ing is the disruption of the given consensus. Wall says, 'right-ing is the moment when a group exceeds the rights that are given to them in order to reconstruct the social bond ... right-ing is the unauthorisable call to exceed human rights (and the given order of things and people)' (p. 108).

This sounds very much like revolution! Douzinas's exploration of the relationship between revolution and right commences with Locke and Burke, then Kant, Hegel and Marx; centrally it concerns the relation of right to morality and legality, and through them the question of revolution. Douzinas, in one of many ringing passages, says 'For the wretched of the earth, right ... is a battle-cry ... the demand not to be treated as an object or as a nobody' (p. 103). This principle, when followed through, authorizes resistance: 'the obligation to obey the law is absolute only when accompanied by the judgment that the law is morally just and democratically legitimate' (p. 105). A right to revolution is problematic because of where it sits between law and morality. The possibility of revolution, as a normative principle our capacity to resist and rebel - is what sustains free action in the world. This free action is seen in the many global sites of resistance of the last several years. These events, in turn, fit perfectly under Wall's description of right-ing: 'It is ruptural, collective and lacks institutional mediation. It is creative and generates new rights, not to ensure their protection by a state, but to begin to fashion a new life' (p. 120).

How should we think about this new life, and how do human rights - or the very idea of the human - help us fashion it? This question is engaged by Drucilla Cornell and Paul Gilroy through the work of Frantz Fanon. Cornell forces us to confront the denial of humanity associated with colonialism, the obliteration of the ethical and the social. She says, 'anything like reciprocity between human beings can only begin in the course of the revolutionary struggle' (p. 124). Revolution is what brings the social into existence and in turn gives new meanings to the human. Gilroy is concerned with reassessing the new humanism that Fanon advocates, arguing that a new humanism must grapple with Europe's ongoing colonialism, racism and criminality. Cornell, 
drawing on Wynter's reading of Fanon, agrees: 'we have yet to begin the history of the human' (p. 130), a history that starts with the right to be human. She agrees with Gilroy that this 'right' 'is inseparable from the struggle against anti-black racism ...' (p. 130). Much of her piece is then a radical Fanonian reworking of human rights, primarily through the thought of Rancière, in order to 'rethink revolutionary possibility against the sorrowful, often self-righteous worldview of a certain human rights discourse' (p. 136). Gilroy, similarly, uses Fanon's humanism to engage human rights discourse, in his case inserting it into contemporary issues of humanitarianism, technology, biometrics and war.

Walter D. Mignolo commences the book's third section, 'Rights, Justice, Politics', by arguing that human rights are under siege by the 'saviors' - actors and institutions usually identified as supportive. He explicates four spheres of the life-world in which human rights are inadequate, limited or counterproductive: migration to the United States and the EU; humanitarian intervention; the mining industry and resource extraction; and the commodification of food. Racism, he argues, "is not a matter of skin color, but of the place people occupy in the ranking of "humanity", (p. 164). Epistemically and geopolitically, a shift is needed, and models need updating. In the age of mega resource extraction, the human rights abuse perpetrator 'is not a totalitarian but a "democratic" state that violates human rights in order to support transnational corporations in the name of development and economic growth' (p. 175). At all levels - ethical, geopolitical, legal and political - human rights must be challenged to decolonize and expand their horizon, pressing against the limits of who gets to claim a place as human.

Mignolo's cosmopolitanism, along with that of other contributors to this volume, including Bruce Robbins and Paul Gilroy, is discussed by Chantal Mouffe cosmopolitanisms which, she says, are formulated to take account of the general criticisms of the Kantian project, and which attend to history and power. 'Their aim is to foster a sense of reciprocity and solidarity at the transnational level and they want to bring to the fore the negative consequences of the economic, political and cultural neoliberal model' (p. 184). Mouffe is not convinced: she argues that the 'new' cosmopolitanism "misses "the political" in its antagonistic dimension ... what is absent ... is the necessary conflictual character of pluralism' (pp. 184-185). Mouffe tells us to forget getting beyond hegemony in a unipolar world, and to develop a polycentric world order, a multipolar world based on regional organization. Strangely missing from her otherwise rich reflections is a theory of how her agonistic pluralism refrains from becoming antagonistic struggle - especially in the absence of that human commonality used to address this very point in the work of the 'new' cosmopolitans.

How to understand this human commonality is a central theme in Samuel Moyn's essay. Moyn considers various contenders for the historical breakthrough point at which our common humanity was discovered or invented, and overlays this with an interrogation of the desire for there to be such a breakthrough point - a point that 'then sets the stage for, or even covers, modern notions of human rights'. 
He continues, 'It is this premise, the universal notion that human universalism is ultimately one thing, that continues to hobble the history of human rights, often presented as the conclusion and culmination of the emergence of cosmopolitanism or universlism' (p. 198). Rather, 'cosmopolitanisms have teemed all along, indeed competed with one another vigorously' (p. 199). The same turns out to be true for human rights - there is no originary breakthrough point that leads to a linear development of human rights into a universal political project, which the term is often taken to embody today. Rather, the history of human rights is the history of a variety of projects, often in competition with one another and, in their contemporary, universalizing form of today, quite at odds with their immediate predecessor, the rights of man and the citizen. It turns out that we invent human rights as we go along - grist to the mill for those seeking to further re-invent human rights.

The final section, 'Rights and Power', commences with Pheng Cheah's claim that the juridical form of human rights is deformed or even exploded by its extension to economic, social and cultural rights (ESCR). The problem with ESCR is their relationship with the fulfillment of human needs, and human needs are not related to the juridical form of self-determination, but rather, to life. 'Humanity cannot be completely self-determining because there cannot be any ultimate human sovereignty over life' (p. 221). What there is, instead, is the inscription of ESCR into global development discourse, a central feature of which is human capacity building which while being something we cannot not want for people, is also something we know can have 'disastrous consequences for the very subjects whose rights are to be realized' (p. 225). Cheah describes this dynamic as a 'machine of simultaneous enablement and limitation, where freedom and constraint, production and regulation are the very same thing'. The rights enabled for these humans can only be understood, argues Cheah, through a biopolitical analysis.

From this vantage point, while appeals to rights may be, as Paul Patton says, 'an especially potent form of social and political criticism', we can also see why it is, as he also comments, that 'the appeal to rights has fallen out of favor for many on the left in recent years' (p. 233). Many of those recommending the abandonment of rights-talk draw from the theoretical resources of Foucault and Deleuze, as indeed does Patton; but he draws a different conclusion, arguing that Foucault and Deleuze 'provide grounds for an alternative response to the criticism of rights that does not abandon rights altogether, but rather the received view of rights as universal and a-historical' (p. 233). Patton takes us through some of the now standard critiques of rights from the left, before treating the thought of Deleuze and Foucault on the creation, and emergence (respectively), of rights. He argues that 'in different ways both Foucault and Deleuze conceive of rights as embedded in relations of power, in discursive representations of the nature and functions of power, and in structures of belief and affect that underpin the considered opinions of a people' - which all leads Patton in the end to endorse a French theoretic-inflected Rawlsian reading of rights as historical and political. 
A different historical reading comes from Bruce Robbins, one granting space for cautious achievements in emancipatory politics. These take place in dirty, impure contexts, 'shaped and tainted by the structures of inequality and injustice that they were contesting' (p. 252). Here Robbins has his sights set on 'an intellectual syndrome' he claims to be common in writing on the history of human rights. Those affected 'speak the language of politics, but, demanding above all else moral purity as judged by today's standards, are unprepared for any of the messiness of historical struggle' (p. 253). His most significant target is Rancière, whom he engages via Sartre's preface to Fanon's The Wretched of the Earth. Robbins critiques Rancière with respect to both egalitarianism and human rights. Rancière cannot explain how the former is instituted, and the latter, understood as action not possession, passes with its moment. Robbins prefers to put his lot in with Balibar, who - also engaged with Sartre, Rancière and Algeria - speaks of rights achieved through a revolution already made, despite always needing to be remade and re-begun. Progress, dirty and political, is possible.

Our current environment is one in which corporations are seen to be elbowing into the human rights story, bringing the threat of 'discursive colonization' and corruption. Joseph R. Slaughter suggests that this fear gets the story the wrong way round. Perhaps, when we go looking for the legal person who is protected by human rights law, we will not find the human (however that is to be understood), but the corporation. Pace the standard Westphalian story of international relations, states were not the only entities in the international to have rights; in Slaughter's reading, the colonial charter companies of the nineteenth century occupied the position in international space currently said to be occupied by the human being. The history of these companies is read by Slaughter together with an analysis of Defoe's Robinson Crusoe. The novel is read to teach us uncomfortable lessons about who gets to be a person - about whether being a human has much to do with it at all. Imperial capitalism is demonstrated to be deeply embedded in the evolution of human rights claims, and Slaughter argues that 'figuring the human being through the vehicle of the person in international law' can be 'a risky business' (p. 297). Corporations may have 'already outcompeted human beings for both their natural resources and rights' (p. 296).

In the final essay of the volume, Slavoj Žižek draws on an extraordinary range of stories, incidents, philosophical and literary scenes and the like to show us how we might have - but not have - human rights. He shows how it is that those who have suffered human rights as imperialistic humanitarianism, might nonetheless find some use for them in their pursuit of justice. Žižek makes these two points, in particular, with the opera Figaro (in versions by Mozart and Rossini) and by discussion of Mexico's Virgin of Guadalupe. In between there is quite a lot of Freud and Marx, North Korea's most popular song, Australia's anti-smoking plain-packaged cigarettes campaign, the documentary movie The Act of Killing, a figure from a Brecht play, and Peng Yu, a Chinese man who accidentally knocked an old lady over and 
then got into trouble for helping her. With his initial story, Žižek wants us to consider what it means for a society, the institutions of which are built on great norms, to step by step lose the substance of those norms while retaining their form; what it will mean when those who see this are prohibited from speaking of it; and further, the consequence if this prohibition cannot be publicly stated. This discussion is centrally about relations of domination, which are connected to human rights norms through a discussion of the way the Sarajevo crisis of the early 1990s was presented as 'humanitarian'. By concluding with the Virgin of Guadalupe, Žižek makes his point most clearly (and most optimistically): 'With her appearance, Christianity, which up to that point had acted as the imposed ideology of the Spanish colonizers, was appropriated by the indigenous population and became a symbol of their terrible plight. This is perhaps the way human rights work today for the exploited and dominated people of the world' (p. 318).

The various essays contained in these two volumes are rich, eloquent, sometimes disturbing and, for the reviewer, very difficult to do justice to in a few short paragraphs. The human rights movement itself continues to capture the imagination of many who would change the world for the better. The critical research agenda that is manifest in these pages, while being salutary and cautionary, is also a great boon for those seriously grappling with how to manifest emancipatory and justice-oriented change in the world. The collected essays add to the growing literature in critical human rights studies, and do so in a way that should spur its further growth and development, and inspire others in the pursuit of critically engaged advocacy, activism and research.

Anthony J. Langlois

Flinders University, Adelaide, Australia 